\title{
PENENTU BRAND AWARENESS PADA APLIKASI OJEK ONLINE (GOJEK)
}

\section{Sugiono ${ }^{1}$, Suwitho ${ }^{2}$, Suhermin ${ }^{3}$}

1 Sekolah Tinggi Ilmu Ekonomi Indonesia (STIESIA) Surabaya, sugionoadventure@gmail.com 2Sekolah Tinggi Ilmu Ekonomi Indonesia (STIESIA) Surabaya, suwitho@stiesia.ac.id 3Sekolah Tinggi Ilmu Ekonomi Indonesia (STIESIA) Surabaya, suhermin@stiesia.ac.id

\author{
ARTICLE INFO \\ Keywords : \\ Brand Awarness, Ojek Online, Technology, \\ Gojek

\section{Kata kunci :} \\ Brand Awarness, Ojek Online, Teknologi, \\ Gojek
}

\section{How to cite :}

Sugiono., Suwitho., Suhermin., (2019).

Penentu Brand Awareness Pada Aplikasi

Ojek Online (GOJEK), 8(3),280-294

DOI :

http://dx.doi.org/10.29303/jmm.v8i3.442

$\begin{array}{ll}\text { Dikumpulkan } & \text { :25 Juni } 2019 \\ \text { Direvisi } & : 12 \text { Juli } 2019 \\ \text { Dipublikasi } & : 18 \text { Juli } 2019\end{array}$

\section{ABSTRACT}

PT. Go-Jek is one of the online based transportation in Indonesia. The purpose of analyzing gojek brand awareness determinants and how informants' perceptions of go-ahead steps in maintaining brand awareness. This type of research uses the qualitative method of the interpretive paradigm. The informants are from Airlangga University students and the people in Surabaya who use the gojek application. The results of the analysis show that there are five factors that determine brand awareness. First, the products, students of Airlangga University and the community were satisfied. Both prices, cheap and affordable. The third easy way to get drivers, is a determinant when consumers go easy to get drivers. The fourth promotion, to attract the attention of consumers to always use the services of these entities. The five services provided by drivers, motorcycle taxi is a measure of the success of motorcycle taxi.

PT. Go-Jek merupakan salah satu transportasi berbasis online di Indonesia. Tujuan untuk menganalisis faktor penentu brand awareness go-jek dan bagaimana persepsi informan terhadap langkah-langkah go-jek dalam mempertahankan brand awareness. Jenis penelitian ini menggunakan metode kualitatif paradigma interpretif. Adapun informannya dari mahasiswa Universitas Airlangga dan Masyarakat di Surabaya yang menggunakan aplikasi gojek. Hasil analisis menunjukkan bahwa terdapat lima faktor penetu brand awareness. Pertama produk, mahasiswa Universitas Airlangga dan masyarakat merasa puas. Kedua harga, harganya murah dan terjangkau. Ketiga kemudaham mendapatan driver, menjadi penentu ketika konsumen gojek mudah mendapatkan driver. Keempat promosi, untuk menarik perhatian konsumen agar selalu menggunakan jasa dari entitas tersebut. Kelima pelayanan yang diberikan driver, gojek merupakan tolak ukur keberhasilan gojek.

Copyright @ 2019 JMM UNRAM. All rights reserved. 


\section{PENDAHULUAN}

Teknologi saat ini memiliki peran penting dalam kehidupan manusia. Teknologi dapat dimanfaatkan untuk mempermudah kehidupan dan menjadi solusi dari berbagai masalah, seperti mempermudah mendapatkan layanan jasa pembelian makanan secara online, mudah dalam mengirimkan barang, serta kemudahan mendapatkan transportasi online untuk melakukan berbagai aktivitas baik bekerja, kuliah maupun mengantarkan anak berangkat sekolah (Hayati, 2016). Maraknya transportasi online yang berkembang di Indonesia khususnya di kota-kota besar menjadi alternatif baru bagi masyarakat, karena lebih efektif dan efisien. Salah satu transportasi online yang fenomena adalah PT. Go-Jek.

PT. Go-Jek merupakan salah satu transportasi berbasis online di Indonesia. Hadirnya Gojek sebagai bentuk implikasi dari meluasnya penggunaan internet dan smartphone di tengah masyarakat serta perkembangan teknologi. Kemunculan aplikasi ojek online telah mengubah perilaku sebagian orang untuk mendapatkan layanan ojek (Wahid dan Puspita, 2017). Berdasarkan hasil survey Kominfo menyebutkan bahwa kurang lebih $98 \%$ anak muda Indonesia memiliki smartphone. Sebanyak 71\% dari mereka mengakses internet setiap hari dengan durasi yang variatif mulai dari satu jam sekali, tiga jam sekali sampai empat jam sekali (Kominfo, 2018). Dampak tren online ini memberikan dampak negatif terhadap tukang ojek yang tidak go online. Selain itu, layanan ojek online juga semakin berkembang dengan adanya layanan paket barang dan antar makanan. Terutama dalam dunia bisnis, digunakan sebagai sarana pemasaran produk.

Adanya gojek di era sekarang merupakan salah satu implementasi revolusi di era industri 4.0, di mana masyarakat diharuskan berhadapan dengan era ekonomi digital. Sehingga saat ini seluruh masyarakat dapat melihat efek dari adanya internet, termasuk efek terhadap dunia usaha. Wabah era industri 4.0 terhadap dunia usaha dapat dirasakan di Indonesia, misalnya gojek menjadi solusi kemacetan di kota-kota besar, dengan pelayanan yang nyaman dan ongkos yang murah (Akbar, et al., 2018)

Jumlah pengguna internet di Indonesia setiap tahun meningkat, pada tahun 2017 mencapai 143,26 juta jiwa atau setara 54,7 persen dari total populasi penduduk Indonesia. Angka tersebut meningkat dibandingkan data pengguna tahun 2016 yang hanya 132,7 juta jiwa (APJII, 2018). Kenaikan jumlah pengguna internet sangat signifikan. Berdasarkan data yang dihimpun oleh Asosiasi Penyelenggara Jasa Internet Indonesia (APJII) kenaikan jumlah pengguna internet dalam setahun sekitar 15 persen dan peningkatan tersebut akan berdampak pada peningkatan pengguna transportasi ojek online.

Transportasi ojek berbasis online sangat membantu dalam mengefektifkan dan mengefesienkan untuk menghadapi kemacetan di kota-kota besar. Fenomena tersebut menjadikan Go-Jek menjadi transportasi alternatif pilihan berbagai masyarakat. Kepopuleran Go-jek dalam beberapa tahun terakhir sehingga menyebabkan beberapa entrepreneur mengikuti jejak Go-Jek dengan mendirikan perusahaan saingan ojek berbasis online juga seperti Grab, Anterin, Golek, Lojek (Hardian, 2018).

Pada tahun 2019 go-jek menyandang status decacorn. Decacorn merupakan julukan startup yang memiliki valuasi di atas US\$10 Miliar atau setara Rp. 140 Miliar. Bisnis gojek bertumbuh pesat selama 10 tahun terakhir berdasarkan dokumen elektronik yang didapat CNBC Indonesia, saat ini go-jek telah menangani 3 juta lebih order setiap hari. Pemesanan ini ditangani oleh lebih dari 2 juta driver (Franedya, 2019). Sehingga tidak salah jika go-jek dianggap sebagai unicorn masa kini. Namun hal itu harus tetap dipertahankan oleh gojek, agar dapat bersaing dengan entitas lain. 
Perusahaan pesaing mengharuskan Go-Jek berupaya untuk memenangkan persaingan bisnis tersebut dengan melakukan berbagai aktivitas untuk peningkatan kesadaran merek di tengah masyarakat. Go-jek selalu berusaha memenangkan persepsi positif dari masyarakat sehingga menumbuhkan image positif yang memperkuat kesadaran merek dengan kata lain supaya Go-jek mendapatkan posisi top of mind pada masyarakat indonesia.

Wahid dan Puspita (2017) meneliti tentang upaya untuk meningkatkan brand awareness Gojek melalui aktivitas Marketing Public Relations (MPR) dengan menggunakan metode P.E.N.C.I.L.S hasil penelitian membuktikan bahwa terdapat peningkatan brand awareness Go-jek di masyarakat. Hayati (2016) melakukan analisis terhadap strategi MPR dalam upaya memasarkan Go-jek sebagai sarana transportasi berbasis teknologi. MPR menggunakan strategi push, pull dan pass, seperti pembuatan meme mengenai Go-jek dan compaign dengan mengangkat isu nasionalisme. Go-jek di berbagai sosial media sehingga secara tidak langsung Go-jek mendapat antusias masyarakat dengan baik. Pratiwi dan Rahanatha (2016) melakukan penelitian terhadap peran brand awareness memediasi daya tarik iklan terdapat brand attitude. Berdasarkan penelitiannya menunjukkan bahwa daya tarik iklan dan brand awareness masing-masing berpengaruh positif dan signifikan terhadap brand attitude.

Brand awareness (kesadaran akan sebuah merek) merupakan kemampuan suatu merek untuk muncul dalam benak konsumen ketika mereka sedang memikirkan kategori produk tertentu dan seberapa mudah nama tersebut dimunculkan. Kesadaran merek adalah dimensi dasar dalam brand equity (Karunanithy dan Sivesan, 2013). Tulasi (2012) menyebutkan bahwa cara pandang konsumen terhadap sebuah merk adalah tidak mempunyai ekuitas hingga konsumen menyadari keberadaan merk tersebut. Brand awareness sebagai kesanggupan seorang calon pembeli untuk mengenali, mengingat kembali suatu merek sebagai bagian dari suatu kategori produk tertentu (Wahid dan Puspita, 2017). Mencapai kesadaran akan merek merupakan tantangan utama bagi merek baru dan mempertahankan tingkat kesadaran akan merek yang tinggi adalah tugas yang harus dihadapi oleh semua jenis merk.

Hayati (2016) menyatakan bahwa Gojek sudah mencapai pada tingkat kesadaran merek tinggi (top of mind) di hati masyarakat indonesia, tantangan selanjutnya adalah pembaharuan langkah apa yang akan dilakukan Go-jek untuk mempertahankan posisi yang sudah di dapatkan selama ini dan faktor penentu apa yang dapat mempertahankan sebuah brand awareness di masyarakat Indonesia. Sehingga peneliti mengangkat judul "penentu brand awareness pada aplikasi ojek online (Go-Jek)".

Dalam penelitian ini penulis merumuskan dua rumusan masalah diantaranya sebagai berikut:

1. Faktor apa yang menjadi penentu dalam peningkatan brand awareness pada aplikasi ojek online (Go-Jek)?

2. Bagaimana persepsi Informan terhadap langkah - langkah Go-Jek dalam mempertahankan brand awareness?

\section{TINJAUAN TEORITIS}

\subsection{Brand Awareness}

Brand awareness (kesadaran merek) adalah kemampuan sebuah merek untuk muncul dalam benak konsumen ketika mereka sedang memikirkan kategori produk tertentu dan seberapa mudah nama tersebut muncul Pratiwi dan Rahanatha, (2016). Definisi lainnya

jmm.unram.ac.id 
menyatakan bahwa brand awareness sebagai kesanggupan seorang calon pembeli untuk mengenali, mengingat kembali suatu merek sebagai bagian dari suatu kategori produk tertentu (Wahid dan Puspita, 2017).

Ada dua hal pokok dari dasar brand awareness yaitu brand recognition dan brand recall performance. Brand recognition (mengenal suatu merk) berhubungan dengan suatu kemampuan konsumen untuk menyikapi dan mengkonfirmasi suatu merk, ketika mereka diberikan atau tidak diberikan suatu tanda atau bantuan (stimulus). Brand recall dihubungkan pada kemampuan konsumen dalam menemukan atau mencari merk ketika ada kategori produk dimunculkan dalam benaknya dengan kata lain brand recall menghendaki konsumen secara rasional mengeneralisasi merk yang sesaat muncul dalam benaknya dan secara sadar akan memilih salah satu diantara yang terbaik. Tanpa suatu tanda (unaided recall) merupakan kemampuan atau kesadaran konsumen dengan kebutuhan asosiasi pemikiran dan kesadaran yang kuat berhubungan dengan merek tersebut (Pratiwi dan Rahanatha, 2016); (Tulasi, 2012).

\subsection{Teknologi dalam Peningkatan Brand Awareness}

Penggunaan teknologi dipengaruhi oleh dua faktor yaitu perceived usefulness (persepsi kemanfaatan) adalah suatu tingkat kepercayaan individu bahwa dengan penggunaan teknologi akan meningkatkan kinerjanya dan perceived ease of use (persepsi kemudahan penggunaan) adalah tingkat kepercayaan individu bahwa dengan penggunaan teknologi membuat pekerjaan lebih mudah diselesaikan (Lavenia et. al., 2018). Sehingga penggunaan dan pemanfaatan teknologi yang ada saat ini dapat memberikan keuntungan terhadap konsumen yang menggunakannya.

\subsection{Market Public Relations (MPR)}

Hayati (2016) menjelaskan bahwa Marketing Public Relations sebagai sebuah proses perencanaan, eksekusi dan evaluasi program-program yang mendorong atau mengajurkan pembelian dan kepuasan konsumen melalui komunikasi yang kredibel dalam menyampaikan informasi dan menciptakan impresi yang mengidentifikasi perusahaan dan produknya dengan kebutuhan, keinginan, perhatian dan kepentingan konsumen. Marketing Public Relations (MPR) sangat erat kaitannya dalam membangun brand awareness dan future market serta mendidik konsumen dan masyarakat mengenai manfaat produk atau jasa yang ditawarkan (Soemirat dan Elvinaro, 2008).

MPR penekanannya bukan pada selling (seperti pada iklan) akan tetapi lebih berperan dalam pemberian informasi, pendidikan dan upaya peningkatan pengertian lewat penambahan pengetahuan mengenai suatu produk/jasa/perusahaan akan lebih kuat dampaknya dan agar lebih lama diingat oleh konsumen, berdasarkan hal tersebut MPR berarti konsep yang lebih tinggi dan lebih lengkap dari iklan biasa (Tulasi, 2012). Adapun penjelasan untuk masing-masing point sebagai berikut Hayati, (2016) : publications (publikasi dan publisitas), event (penyusunan program acara), news (menciptakan berita), community involvement, inform or image, lobbying and negotiation dan social responsibility

Keberadaan MPR dalam sebuah perusahaan dianggap sangat efektif, dikarenakan MPR mampu membangun brand awareness (kesadaran akan merek) dan brand knowledge (pengetahuan akan merek), berpotensi untuk membangun efektifitas pada area "increasing category usage" dan "increasing brand sales" , MPR juga mampu menekan biaya anggaran (lebih hemat) daripada perusahaan yang memasukkan produknya melalu iklan (Maryam dan Wirman, 2017). 


\subsection{Faktor yang Mempengaruhi Konsumen}

Berdasarkan penelitian yang dilakukan oleh Anggraini (2017) ada beberapa faktor yang mempengaruhi konsumen dalam pemakaian jasa ojek online yaitu produk (product), harga (price), saluran distribusi (place), promosi (promotion), orang (people), bukti fisik (physical evidence), dan proses (process) atau lebih dikenal dengan 7P.

a. Produk (product), menurut Kotler dan Keller, (2000) dalam pembelian produk konsumen melihat pada diferensiasi yang dimiliki oleh produk tersebut, diferensiasi produk antara lain bentuk, fitur, penyesuaian, kualitas kinerja, kualitas, kesesuaian, ketahanan, keandalan, kemudahan perbaikan, gaya, desain.

b. Harga (price), menurut Tjiptono (2004) dalam Anggraini (2017) menyatakan pada dasarnya tujuan penetapan harga yaitu berorientasi pada laba, volume, citra dan harga.

c. Saluran distribusi (place), Kotler dan Amstrong (2008) dalam Anggraini (2017) menyatakan bahwa place adalah kegiatan yang dilakukan perusahaan untuk membuat produk tersedia bagi sasaran pelanggan.

d. Promosi (promotion), merupakan suatu kegiatan yang sangat penting dilaksanakan oleh perusahaan dalam memasarkan produknya.

e. Orang (people), orang mempunyai peran penting dalam pemasaran jasa yang mengarah pada minat yang lebih besar dalam pemasaran internal.

f. Bukti fisik (physical evidence), merupakan suatu hal yang turut mempengaruhi keputusan konsumen untuk membeli dan menggunakan produk jasa yang ditawarkan.

g. Proses (process), yaitu semua prosedur aktual, mekanisme dan aliran aktivitas dengan nama jasa yang disampaikan yang berarti sistem penyajian atau pelayanan jasa (Anggraini, 2017).

\subsection{Kepuasan Pelanggan}

Menurut Kotler dalam penelitian Lavenia, et. al (2018) menyebutkan bahwa kepuasan pelanggan adalah tingkat perasaan seseorang setelah membandingkan (kinerja atau hasil) apa yang dirasakan dibandingkan dengan harapannya. Konsumen akan merasa kecewa apabila kinerja dibawah harapan dan konsumen akan merasa puas apabila kinerja sesuai dengan harapan dan akan merasa sangat puas atau gembira apabila kinerja melebihi harapan.

Kotler menjelaskan kunci untuk mempertahankan pelanggan yaitu kepuasan konsumen. Adapun indikator untuk kepuasan konsumen terdiri dari :

a. Re-purchase yaitu membeli kembali, yang mana pelanggan tersebut akan kembali pada perusahaan untuk mencari barang/jasa.

b. Menciptakan Word-of-Mouth, hal ini berarti pelanggan akan mengatakan hal yang baik terhadap produk/ jasa bahkan tentang perusahaan kepada orang lain.

c. Menciptakan citra merek, apabila perusahaan sudah menjadi top of mind brand maka pelanggan tidak akan memperhatikan merek dan iklan dari produk/ jasa pesaing.

d. Menciptakan keputusan pembelian pada perusahaan yang sama yakni membeli produk lain dari perusahaan yang sama.

\subsection{Penerapan metode TAM (Technology Acceptance Model)}

TAM merupakan suatu model untuk menjelaskan dan memprediksi bagaimana pengguna teknologi menerima dan menggunakan teknologi yang berkaitan dengan pekerjaan pengguna. Model TAM berasal dari teori psikologi untuk menjelaskan perilaku pengguna teknologi informasi berdasarkan kepercayaan (belief), sikap (attitude), niat (intention) dan hubungan perilaku pengguna (user behavior relationship). Teori tersebut 
dapat membuat model perilaku seseorang sebagai fungsi dari tujuan perilaku. Tujuan dari perilaku ditentukan oleh sikap atas perilaku tersebut (Syahputra, 2016). Tujuan utama TAM yaitu menjelaskan faktor-faktor utama dari perilaku pengguna teknologi informasi terhadap kepercayaan, sikap dan tujuan teknologi informasi itu sendiri (Lavenia et al., 2018).

\section{METODE PENELITIAN}

\subsection{Jenis Penelitian dan Lokasi Penelitian}

Jenis penelitian ini ialah penelitian kualitatif dengan menggunakan paradigma interpretif. Alasannya digunakan paradigma interpretif dalam penelitian ini ialah karena paradigma interpretif dapat membantu peneliti dalam melihat lebih dalam realitas sosial yang ada, dengan demikian dapat menentukan apakah realitas tersebut hanyalah suatu simbol atau ide yang dimunculkan ataukah benar merupakan suatu kenyataan dari suatu permasalahan. Sehingga dengan menggunakan paradigma interpretif peneliti dapat menganalisis faktor penentu brand awareness pada go-jek dan menganalisis langkah-langkah go-jek dalam mempertahankan brand awareness di masyarakat.

Adapun penelitian ini akan dilaksanakan di Surabaya tepatnya di Universitas Airlangga Surabaya. Alasan memilih lokasi ini karena mahasiswa Universitas Airlangga Sering menggunakan transporatasi ojek online yakni Go-Jek. Kemudian padatnya kendaraan di Kota Surabaya menjadikan gojek sebagai salah satu pilihan transportasi masyarakat Surabaya. Memudahkan penulis untuk mengefisiensikan waktu dan kemudahan fasilitas, data dan informasi serta bahan pendukung lainnya. Penelitian akan dilaksanakan dari bulan Desember 2018 sampai Maret 2019.

\subsection{Teknik Penentuan Informan}

Teknik penentuan informan dalam penelitian ini diambil secara purposive (sengaja) dengan berdasarkan kriteria yang telah ditetapkan peneliti untuk dapat menjawab rumusan masalah. Adapun kriteria informan yang dipilih (1) Mahasiswa Unair (Universitas Airlangga) Surabaya yang menggunakan aplikasi Go-jek. (2) Masyarakat pengguna aplikasi Go-jek di Surabaya.

\subsection{Teknik Pengumpulan Data}

Penelitian ini menggunakakan 3 teknik pengumpulan data yakni:

\section{Observasi Partisipan}

Observasi partisipan dalam penelitian ini ialah observasi yang dilakukan oleh peneliti, di mana peneliti mengambil peran dalam situasi yang berlangsung. Hal ini dilakukan agar peneliti mendapatkan pengalaman secara langsung dari aktivitas tersebut sehingga informasi yang diperoleh menjadi mendalam. Observasi partisipan dapat mengoptimalkan kemampuan peneliti dari segi motif, kepercayaan, perhatian, perilaku tak sadar, kebiasaan, dan sebagaianya. Pengamat memungkinkan melakukan observasi dengan melihat dunia sebagai mana yang dilihat oleh subjek penelitian, menangkap arti fenomena dari segi pengertian subjek, menangkap kehidupan budaya (culture) dari segi pandangan dan anutan para subjek pada keadaan waktu itu. Dengan pengamatan memungkinkan peneliti merasakan apa yang dirasakan dan dapat dihayati oleh subjek sehingga peneliti juga dapat menjadi sumber data. Pembentukan pengethauan melalui pengamatan yang diketahui bersama, baik dari pihaknya atau dari pihak subjek.

\section{Wawancara Semi Terstruktur}


Teknik pengumpulan data dalam penelitian ini menggunakan wawancara semi terstruktur, hal ini dilakukan untuk menemukan permasalaha secara lebih terbuka. Di mana dalam penelitian ini peneliti telah mempersiapkan pertanyaan yang umum berdasarkan garis-garis besar permasalahan kemudian akan berkembang ketika di lapangan. Peneliti hanya memberi petunjuk wawancara yang berisi petunjuk secara garis besar tentang proses dan isi wawancara untuk menjaga agar pokok-pokok yang sudah direncanakan dapat tercakup atau tertuang seluruhnya. Kemudian disertai pertanyaanpertanyaan yang justru nantinya dapat memancing subjek penelitian untuk lebih terbuka dan jujur seperti kenyataanya.

\section{Dokumentasi}

Mencari literatur dapat dilakukan dengan dokumentasi yang relevan dengan topik penelitian berupa majalah, tabloid, artikel, maupun jurnal penelitian yang sesuai dengan topik bahasan penelitian ini. Adapun dokumentasi menjadi penting dalam penelitian kualitatif dikarenakan selain sifatnya yang alamiah, kesesuaian dengan konteks, lahir dan berada dalam koneks juga setelah dapat hasil pengkajian isi akan membukan kesempatan untuk dapat lebih memperluas pengethauan terhadap sesuatu yang diselidiki.

\section{Satuan Kajian}

Pada penelitian ini satuan kajian mengungkapkan hal-hal yang dibahas oleh peneliti dalam penelitiannya, sehingga akan mengarahkan perhatian peneliti terhadap sesuatu yang akan diteliti. Fokus penelitian ialah faktor penentu brand awareness pada go-jek dan persepsi Informan terhadap langkah-langkah go-jek dalam mempertahankan brand awareness. Sehingga peneliti berfokus pada kesadaran masyarakat dalan penggunaan brand awareness pada go-jek

\section{Analisis Data}

Data dan informasi yang sudah terkumpul demikian banyak dan kompleks serta masih tercampur aduk direduksi dengan cara memilih yang relevan dengan topik penelitian yang disajikan. Dalam hal ini proses pemilihan data difokuskan pada data yang mengarah ke pemecahan masalah, penemuan, pemaknaan atau untuk dapat menjawab pertayaan penelitian. Data dan informasi berbagai pemaknaan dan tetang permasalahan penelitiam diformulasikan secara lebih sederhana, juga disusun secara sistematis dengan menonjolkan abstraksi yang lebih akurat dan tajam sehingga kebermaknaan hasil temuan. Kemudain teknik triagulasi dapat digunakan untuk mengecek kebenaran temuan data dan informasi dengan melakukan kroscek pada berbagai informan kunci dalam penelitian. Validasi data dalam penelitian ini juga dengan cara membandingkan data antar kampus atau perumahan yang menjadi objek penelitian. Penyajian data dan informasi hasil dari penelitian selanjutnya dapat disajikan dalam bentuk narasi wawancara agar lebih mudah dipahami interaksi antar bagian-bagian daam konteks yang utuh. Akhirnya peneliti menarik kesimpulan atau verifikasi keterkaitan antar informan-informan dalam penelitian berdasarkan fakta temuan-temuan dilapangan. Verifikasi dilakukan dengan tujuan agar dapat memperoleh konsensus atau komfirmabilitas atas interpretasi tentang permasalahan penelitian.

\section{HASIL DAN PEMBAHASAN}

\subsection{Gambaran Umum PT. Go-Jek}

PT. Go-Jek didirikan oleh Nadiem Makarim yang bersifat bisnis startup, terdapat misi sosial yang diemban ketika mendirikan Go-Jek, yakni meningkatkan penghasilan para supir ojek. Kemacetan semakin padat, sehingga ojek online harusnya bisa menjadi solusi 
alternatif untuk masyarakat ibu kota. Alasan tersebut yang melahirkan gagasan untuk menciptakan layanan transportasi antar yang praktis \& cepat untuk membantu masyarakat pengguna ojek, sekaligus membantu para supir ojek agar bisa bekerja lebih produktif. Hingga pada tahun 2010, akhirnya Go-Jek diluncurkan dan mulai beroperasi (Go-jek.com, 2019)

GO-JEK kini telah tumbuh menjadi on-demand mobile platform dan aplikasi terdepan yang menyediakan berbagai layanan lengkap mulai dari transportasi, logistik, pembayaran, layan-antar makanan, dan berbagai layanan on-demand lainnnya. Gojek mempunyai 3 pilar yaitu kecepatan, inovasi dan dampak sosial. Kecepatan maksudnya melayani dengan cepat, dan terus belajar dan berkembang dari pengalaman. Inovasi artinya terus menawarkan teknologi baru untuk mempermudah hidup Anda. Dampak Sosial dengan maksud untuk memberikan dampak positif sosial sebesar-besarnya bagi masyarakat Indonesia (Go-jek.com, 2019).

Adapun beberapa fitur dari gojek adalah Fitur dan layanan GO-JEK antara lain: layanan transportasi barang (GO-SEND), layanan transportasi penumpang dengan sepeda motor (GO-RIDE), layanan pemesanan makanan (GO-FOOD), layanan berbelanja (GO$M A R T)$, layanan pengantaran barang berukuran besar (GO-BOX), layanan membersihkan rumah (GO-CLEAN), layanan kecantikan (GO-GLAM), layanan pemijatan (GO-MASSAGE), layanan direktori (GO-NEARBY), layanan pemesanan tiket (GO-TIX), layanan transportasi dengan mobil (GO-CAR), layanan montir (GO-AUTO), layanan pembelian obat (GO-MED), layanan isi pulsa elektronik (GO-PULSA), layanan belanja barang (GO-SHOP), layanan transportasi dengan taksi reguler (GO-BLUEBIRD) Blue Bird Group (kerjasama), layanan bebagai pembayaran (GO-BILLS), layanan pembayaran digital (GO-PAY), layanan penawaran diskon (GO-DEALS) (Go-jek.com, 2019)

\subsection{Gambaran Umum Informan}

Informan dalam penelitian ini ialah mahasiswa Universitas Airlangga dan Masyarakat. Dibawah ini disajikan tebel gambaran umum informan :

Tabel 1. Gambaran Umum Informan

\begin{tabular}{llccl}
\hline \multicolumn{1}{c}{ NAMA } & \multicolumn{1}{c}{ STATUS } & $\begin{array}{c}\text { AWAL } \\
\text { MENGGUNAKA } \\
\text { N GOJEK }\end{array}$ & $\begin{array}{c}\text { JUMLAH } \\
\text { PENGUNAAN } \\
\text { APLIKASI } \\
\text { GOJEK }\end{array}$ & ASAL INFORMAN \\
\hline Zaki & Manajemen (S-1) & 2018 & 1 Kali & Mahasiswa Universitas Airlangga \\
Gandi & Manajemen (S-2) & 2017 & Lebih Dari 20 & Mahasiswa Universitas Airlangga \\
Reyhan & Akuntansi (S-2) & 2017 & Lebih Dari 20 & Mahasiswa Universitas Airlangga \\
Toni & Kenotarisan (S-2) & 2017 & Lebih Dari 10 & Mahasiswa Universitas Airlangga \\
Fira & Kimia (S-1) & 2017 & Lebih Dari 10 & Mahasiswa Universitas Airlangga \\
Tuning S & Karyawan Swasta & 2017 & 100 Kali & Masyarakat \\
Vita Kirana & Ibu Rumah Tangga & 2017 & Lebih Dari 70 & Masyarakat \\
M Naseer & Pegawai Bumn & 2017 & Lebih Dari 50 & Masyarakat \\
Yaslin & Belum Bekerja & 2018 & 2 Kali & Masyarakat \\
\hline
\end{tabular}

Sumber: Data diolah oleh peneliti (2019)

Berdasarkan tabel 1 dapat dilihat bahwa informan dari mahasiswa Universitas Airlangga terdiri atas dua informan dari program sarjana dan tiga informan dari program magister. Informan dari mahasiswa Universitas Airlangga menjawab bahwa awal menggunakan gojek pada tahun 2017 sebanyak 4 informan dan 1 informan pertama kali menggunakannya pada tahun 2018. Informan yang berasal dari mahasiswa Universitas 
Airlangga menjawab bahwa penggunaan aplikasi gojek sudah dilakukan sebanyak satu kali oleh satu informan, lebih dari 10 kali dijawab oleh dua informan, lebih dari 20 kali dijawab oleh dua informan.

Informan dari masyarakat terdiri atas satu informan dari karyawan swasta, satu informan dari ibu rumah tangga, satu informan dari pegawai BUMN, dan satu informan dengan status belum bekerja. Informan dari masyarakat menjawab bahwa awal menggunakan gojek pada tahun 2017 sebanyak 4 informan dan 1 informan pertama kali menggunakannya pada tahun 2018. Informan yang berasal dari masyarakat menjawab bahwa penggunaan aplikasi gojek sudah dilakukan sebanyak dua kali oleh satu informan, lebih dari 50 kali dijawab oleh satu informan, lebih dari 70 kali dijawab oleh satu informan, dan 100 kali dijawab oleh satu informan.

\subsection{Faktor-Faktor yang mempengaruhi Brand Awareness}

Persaingan pasar saat ini menuntut perusahaan untuk saling bersaing dalam hal memasarkan dan menjualkan produknya kepada konsumen (Kumalasari, 2013). Begitu juga dengan gojek, gojek harus mampu memnggunkan starategi yang tepat dalam mempertahankan produknya yang berupa jasa agar tetap dikonsumsi oleh konsumen secara berkelanjutan. Sehingga kesadaran akan produk dari gojek tersebut atau brand awreness gojek mampu muncul dan bertahan dalam benak konsumen. Oleh karena itu gojek harus memperhatikan faktor penentu brand awareness tersebut. Hasil penelitian menunjukkan bahwa terdapat tujuh faktor penentu brand awareness yakni produk, harga, mendapatkan diver, promosi, pelayanan driver, dan proses.

\section{Produk: Puas atau Kecewa}

Perasaan puas atau kecewanya pelanggan timbul ketika konsumen membandingkan persepsi mereka mengenai kinerja produk atau jasa dengan harapan yang mereka inginkan. Tujuan utama dari pemasaran adalah pencapaian pada tingkat kepuasan pelanggan. Ketika pelanggan merasa puas akan pelayanan yang didapatkan pada saat proses transaksi dan juga puas akan barang atau jasa yang didapatkan, kemungkinan besar mereka akan kembali lagi dan melakukan pembelian-pembelian yang lain dan juga akan merekomendasikan pada teman-teman dan keluarganya tentang perusahaan tersebut dan produk-produknya, serta kemungkinan mereka berpaling kepada perusahaan lain akan semakin kecil (Ridho dan Suharyono, 2017). Di mana dalam hal memberikan layanan jasa yang menjadi produk gojek membuat mahasiswa Universitas Airlangga menjadi puas.

Hal ini mencerminkan bahwa mahasiswa Universitas Airlangga merasa puas dengan produk yang dihasilkan oleh gojek itu sendiri. Adanya fitur-fitur yang dapat membantu mereka dalam aktivitas mereka. Tulasi (2012) menegaskan bahwa adanya konsumen yang menikmati dan merasa puas serta menggunakannya secara terus menerus, maka konsumen akan mengarah pada konsumen yang mempunyai tingkat kesetiaan merek yang tinggi. Hal serupa juga disampaikan oleh masyarakat Kota Surabaya yang menjadi informan dari penelitian ini. Bahwa informen yang berasal dari masyarakat Kota Surabaya merasa puas dengan adanya go-jek.

Sehingga baik dari mahasiswa Universitas Airlangga maupun masyarakat Kota Surabaya yang menjadi informan dalam penelitian ini merasa bahwa dengan adanya gojek yang memberikan produknya berupa layanan jasa membuat mereka merasa puas dengan adanya gojek itu sendiri. Wahid dan Puspita (2017) menjelaskan bahwa gojek menjadi transportasi alternative pilihan masyarakat kota yang macet dengan segala fitur yang mendukung seperti dalam hal pengiriman barang (go-send), pesan antar makanan (go-food), berbelanja (go-mart), dan berpergian (go-send) ditengah kemacetan di Kota Surabaya. 
Sehingga dengan adanya go-jek mempermudah mahasiswa Universitas Airlangga dan masyarakat Kota Surabaya melakukan segala aktivitasnya. melalui fitur pesan antar makanan (go-food) yang sangat digemari customer yang memudahkan mahasiwa Universitas Airlangga dalam memesan makanan ketika musim hujan dan pada saat malas keluar dari kosan.

\section{Harga : Murah atau Mahal}

Untuk memberikan rasa kepuasan terhadap pelayanan yang diberikan perusahaan terhadap pelanggan, maka pelanggan akan membayar dengan harga yang layak yang telah ditetapkan oleh perusahaan (Safrizal, 2015). Ketertarikan konsumen dalam menggunakan aplikasi gojek ini sendiri dikarenakan harga yang murah dan terjangkau baik dari kalangan mahasiswa maupun masyarakat.

Persaingan pasar yang sangat ketat saat ini merupakan hal yang harus diprioritaskan oleh perusahaan seperti kualitas pelayanan yang akhirnya akan merimbas pada penetapan harga yang sesuai dengan kondisi perusahaan (Safrizal, 2015). Namun ada juga informan yang membanding gojek dengan ojek online lainnya dari segi harga yang kadang kala dikeluhkan oleh informen baik yang berasal dari mahasiswa maupun masyarakat Kota Surabaya.

Dari hasil wawancara terlihat bahwa informan merasa harga yang diberikan oleh gojek itu murah, namun kadangkala harga yang diberikan oleh gojek itu sendiri mahal tergantung situasi dan kondisi. Di mana harga merupakan salah satu faktor penting dalam brand awareness. Situmeang (2017) menegaskan bahwaa banyak perusahaan yang bangkrut disebabkan oleh perusahaan mematok harga yang tidak cocok. Hal ini dikarenakan harga suatu produk akan menentukan persepsi konsumen mengenai produk tersebut. Hal ini dikhawatirkan jika harga yang ditetapkan oleh gojek lebih mahal dari ojek online lainnya akan menyebabkan konsumen akan berfikir lagi untuk menggunakan produk yang diberikan gojek dan konsumen akan merasa tidak puas.

Untuk mengatasi hal tersebut pemerintah melalu Kementerian Perhubungan telah menetapkan taarif ojek online sejak 26 Maret 2019. Tarif ojek online ini ditetapkan melalui keputusan Menteri Pehubungan tentang Pedoman Perhitungan Biaya Jasa Penggunaan Sepeda Motor yang digunakan untuk kepentingan masyarakat yang dilakukan melalui aplikasi. Peraturan tersebut tertuang dalam Peraturan Menteri Perhubungan Nomor 12 Tahun 2019 tentang perlindungan Keselamatan Pengguna Sepeda Motor yang Digunakan Untuk Kepentingan Masyarakat. Salah satu kota yang telah pemberlakuan tarif tersebut yakni surabaya. Hal ini dilakukan sebagai upaya mitigasi risiko dan mitigasi manajemen dalam penerepan regulasi yang ada (Velarosdela, 2019).

\section{Mendapatkan Driver: Mudah Atau Sulit}

Perusahaan yang bergerak pada bidang jasa harus pandai dalam memilih lokasi sebagai tempat perusahaan tersebut melakukan seluruh aktivitas kegiatannya, karena dengan lokasi yang staregis dan nyaman akan lebih menguntungkan perusahaan (Situmeang, 2017). Hal itu tidak juga perlu diberlakukan pada driver gojek. Hal ini dilakukan agar keterjangkauan lokasi Antara driver dengan konsumen menjadi dekat dan driver dapat bekerja secara cepat. Kemudahan mendapatkan driver menjadi faktor penentu ketika konsumen dari gojek tersebut mudah mendapatkan driver. Hal ini mengisyaratkan bahwa dengan mudahnya mendapatkan driver maka konsumen akan loyal dalam menggunakan aplikasi gojek itu sendiri

Sehingga dapat dilihat bahwa kemudahan dalam mendapatkan driver oleh informan cukup mudah, namun kadang-kadang juga mendapatkan driver diwilayah yang cukup sepi. Driver biasanya mengumpul pada satu titik didekat keramaian seperti wilayah 
perkantoran, pasar, mall, dan lain sebagainya. Dengan adanya lokasi penyebaran driver yang strategis maka dapat menjadi penentu brand awareness gojek, di mana dengan lokasi yang bagus akan mempermudah konsumen dalam menganalisis kebutuhan atau produk. Lokasi yang baik akan menjamin tersedianya akses yang cepat, dapat menarik sejumlah besar konsumen.

\section{4. $\quad$ Promosi : Banyak atau Sedikit}

Sebuah merk mampu menarik minat konsumen dalam memakai produk atau jasa jika memiliki merk yang kuat dan domina di pasaran. Salah satu untuk memperkuat merk di pasaran yakni dengan adanya promo yang diberikan persuhaan. Promosi digunakan untuk menarik perhatian konsumen agar selalu menggunakan jasa dari entitas tersebut. Namun Gojek dinilai kurang memberikan promo-promo yang membuat para konsumennya kurang tertarik untuk melakukan transaksi melui aplikasi gojek itu sendiri.

Promo yang diberikan oleh gojek mendapat kritikan oleh informan. Di mana gojek dirasa masih kurang memberikan promo kepada konsumen, sehingga konsumen tidak secara rutin menggunakan pelayanan yang diberikan oleh gojek. Sehingga diharapkan kepada gojek dapat memperhatikan promo yang diberikan kepada konsumennya, agar gojek dapat memenangkan pasar dibanding dengan ojek online lainnya.

Adanya promosi merupakan salah satu langkah menawarkan insentif dalam priode tertentu untuk mendorong keingin konsumen dan juga akan menjadi salah satu pertimbangan konsumen untuk tertarik menggunakan transportasi online. Adanya promosi akan terjadi pencapaian tujuan gojek itu sendiri serta menjadi daya Tarik tersendiri bagi para konsumen untuk memutuskan penggunaan transportasi online tersebut (Nur'amna, 2018).

\section{Pelayanan Driver: Bagus atau Buruk}

Perusahaan yang mampu memberikan pelayana yang baik kepada konsumen akan membuat citra positif bagi perusahaa. Pelayanan yang baik akan mendorong minat konsumen untuk menggunakan kembali jasa tersebut sehingga terciptanya loyalitas (Wardani, 2017). Adanya pelayanan terbaik yang diberikan oleh perusahaan untuk konsumen akan menjadi tolak ukur keberhasilan sebuah perusahaan. Perusahaan yang berhasil melayani konsumen dengan bagus akan mendapatkan brand yang baik dimata konsumen. Yang akhirnya dengan adanya pelayanan yang bagus akan meningkatkan keloyalitasan pelanggan akan produk atau jasa dari perusahaan tersebut.

Pelayanan yang diberikan oleh gojek merupakan tolak ukur keberhasilan gojek. Adanya pelayanan yang bagus akan berimbas pada kepuasan konsumen yang akhirnya akan membuat konsumen akan terus menggunakannya dalam jangka waktu panjang. Persaingan pada dunia bisnis jasa transportasi online semakin ketat, sehingaa perusahaan gojek harus memberikan kualitas pelayanan yang baik kepada konsumen khususnya para driver gojek. Hal ini dikarenakan driver gojek merupakan orang yang paling bersentuhan langsung dengan konsumen, sehingga diharapkan mereka dapat memberikan pelayanan yang bagus yang akhirnya dapat meningkatkan brand awareness di mata masyarakat. Di mana pelayanan yang diberikan oleh driver gojek kepada konsumen cukup bagus. Namun ada juga yang membantah jika pelayanan yang diberikan oleh driver gojek itu cukup bagus.

Sehingga dapat disimpulkan bahwa pelayanan yang diberikan oleh driver sebagian menjawab cukup bagus. Namun sebagian masih dirasa pelayanan yang diberikan oleh driver gojek kurang bagus hal ini yang akhirnya jika tidak adanya pembinaan dan pengawasan kepada driver akan membuat gojek terkalahkan dengan ojek online lainnya. 


\section{Persepsi Informan terhadap langkah-langkah Go-Jek dalam mempertahankan Brand Awarenes.}

GOJEK adalah sebuah perusahaan teknologi berjiwa sosial yang bertujuan untuk meningkatkan kesejahteraan mitranya di berbagai sektor informal di Indonesia. GOJEK menawarkan 8 (delapan) fitur jasa layanan yang bisa dimanfaatkan oleh para pelanggannya yaitu Go-Send (Pengantaran Barang), Go-Ride (Jasa Angkutan Orang), GoFood (Pesan Makanan), Go-Mart (Belanja), Go-Glam, Go-Massage, Go-Box, Go-Clean, GoBusway, dan Go-Tix. Kegiatan GO-JEK bertumpu pada 3 nilai pokok: kecepatan, inovasi, dan dampak sosial.

\section{Kecepatan}

Di era modern ini masyarakat mempunyai aktivitas yang beragam dan untuk memenuhi aktivitas tersebut masyarakat memerlukan adanya trasnportasi penunjang, salah satunya gojek. Gojek pada era modern ini perlu berhati-hati dalam bersaing. Gojek harus menggaet konsumennya dengan peningkatan pelayanan, kemudaahn pemesanan, kenyamana armada, ketepatan waktu dan lain sebagainya (Zahra, 2017). Untuk mempertahankan brand awareness gojek di mata masyarakat gojek telah melakukan berbagai upaya salah satunya melayani konsumen dengan cepat.

Hal ini dirasakan oleh informan, bahwa dengan adanya gojek itu sendiri memberikan pelayanan yang cepat dalam setiap permintaan konsumen kepada driver. Zahra (2017) menegaskan bahwa kecepatan dalam pelayanan merupakan kunci untuk mencapai kesuksesan. Baik tidaknya kecepatan dalam pemberian pelayanan tergantung pada kemampuan produsen dalam memenuhi harapan konsumen secara konsisten. Kecepatan dalam pelayanan yang diberikan oleh gojek kepada pelanggan dikatakan memuaskan hal ini dikarenakan layanan yang dirasakan oleh informan sama atau melebihi kualitas layanan yang diharapkan.

\section{Inovasi}

Inovasi merupakan proses pengembangan bisnis dan membantu perusahaan beradaptasi dan tumbuh di pasar dengan produk atau proses yang lebih baik dari sebelumnya (Efendi, et al, 2016). Bisnis kreatif dan inivatif yang memanfaatkan teknologi informasi dan komunikasi saat ini yakni gojek. Gojek selalu melakukan inovasi, mulai dari adanya go-pay sebagai alat pembayaran hingga penambahan menu-menu baru dalam aplikasinya.

Adanya gojek yang semakin berinovasi seperti adanya jenis layanan yang disediakan gojek untuk memenuhi keinginan dan kebutuhan pelanggan, mulai dari ojek, pengantar makanan, dokumen dan berbagai layanan lainnya membawa dampak terhadap keberlangsungan peruhaan. Tidak hanya penambahan fitur saja yang menjadi keinovasian yang dimiliki gojek, namun gojek juga memberikan inovasi atas kemudahan konsumen dalam mengakses aplikasi gojek itu sendiri.

Hal ini mengidentifkasikan bahwa gojek selalu melakukan inovasi, yang mana bertujuan untuk memberikan kemudahan dalam pelayanann kepada masyarakat. Sehingga dengan adanya inovasi ini akan membawa dampak terciptanya brand awaraness di mata konsumen tentang gojek itu sendiri.

\section{Dampak Sosial}

Ketersediaan jasa transportasi berkolerasi positif dengan kegiatan perekonomian dan pembangunan dalam masyarakat. Jasa transportasi mempunyai peran penting dalam hal melancarkan arus barang dan mobilitas manusia serta membantu tercapainya alokasi sumber daya ekonomi secara optimal dalam bidang ketenagakerjaan, hal ini berarti kegiatan produksi dapat terlaksanakan dengan efektif dan efisien, kesempatan kerja dan 
pendapatan masyarakat meningkat (Romadhon dan Zainudin, 2018). Dampak sosial adanya gojek sangatlah besar bagi masyarakat. Di mana adanya gojek ini memberikan kemudahan kepada driver dan masyarakat dalam penyedia transportasi umum.

Hal ini mengidentifikasikan bahwa adanya gojek memberikan dampak sosial yang positif bagi konsumennya mauapun driver. Adanya gojek membawa dampak dalam peningkatak ekonomi, dampak nyata dari adanya gojek ini adalah membantu driver maupun mobilitas masyarakt dalam kebutuhan sehari-hari dari segi transportasi umum maupun solusi untuk kebutuhan gaya hidup (lifestayle) mulai dari mengantar barang, makanan, berbelanjaan, dan lain sebagainya (Romadhon dan Zainudin, 2018).

Dampak sosial adanya gojek juga berdampak pada driver. Fasilitas yang didapatkan oleh driver go-jek tidak hanya dari sistem bagi hasil yang menguntungkan mereka juga mengatakan bahwa pendapatan mereka meningkta semenjak bergabung sebagai mitra, merek ajuga mendapatkan santunan kesehatan dan kecelakaan, serta mendapat akses ke lebih banyak pelanggan melalui aplikasi gojek (Septanto, 2016).

\section{KESIMPULAN}

Terdapat lima faktor penentu brand awareness. Pertama produk, di mana mahasiswa Universitas Airlangga dan masyarakat merasa puas dengan produk yang dihasilkan oleh gojek itu sendiri. Adanya fitur-fitur yang dapat membantu mereka dalam aktivitas mereka

Kedua harga, ketertarikan konsumen dalam menggunakan aplikasi gojek ini sendiri dikarenakan harga yang murah dan terjangkau baik dari kalangan mahasiswa maupun masyarakat. Ketiga kemudaham mendapatkan driver, kemudahan mendapatkan driver menjadi faktor penentu ketika konsumen dari gojek tersebut mudah mendapatkan driver. Hal ini mengisyaratkan bahwa dengan mudahnya mendapatkan driver maka konsumen akan loyal dalam menggunakan aplikasi gojek itu sendiri.

Keempat promosi, promosi digunakan untuk menarik perhatian konsumen agar selalu menggunakan jasa dari entitas tersebut. Namun gojek dinilai kurang memberikan promo-promo yang membuat para konsumennya kurang tertarik untuk melakukan transaksi melalui aplikasi gojek. Kelima pelayanan yang diberikan driver, pelayanan yang diberikan oleh gojek merupakan tolak ukur keberhasilan gojek. Di mana pelayanan yang diberikan oleh driver gojek kepada konsumen cukup bagus.

Persepsi Informan terhadap langkah-langkah Go-Jek dalam mempertahankan Brand Awareness di masyarakat pertama kecepatan, untuk mempertahankan brand awareness gojek di mata masyarakat gojek telah melakukan berbagai upaya salah satunya melayani konsumen dengan cepat. Kedua inovasi, gojek selalu melakukan inovasi, mulai dari adanya go-pay sebagai alat pembayaran hingga penambahan menu-menu baru dalam aplikasinya. Ketiga dampak sosial, dampak sosial adanya gojek sangatlah besar bagi masyarakat. Di mana adanya gojek ini memberikan kemudahan kepada masyarakat dalam penyedia transportasi umum.

\section{DAFTAR PUSTAKA}

Anggraini, N. F., (2017), Analisis Faktor-Faktor yang Mempengaruhi Konsumen Menggunakan Jasa Ojek Online. Universitas Muhammadiyah Surakarta.

Anggraini, R.Y., (2017), Masuknya Paradigma Interpretif Pada Kajian Ilmu Akuntansi. Jurnal Analisa Akuntansi dan Perpajakan. Vol 1(1): 51-62.

APJII, (2018), Survei APJII: Penetrasi Internet di Indonesia. Apjii, 3. Retrieved from

jmm.unram.ac.id 
https:// apjii.or.id/downfile/file/BULETINAPJIIEDISI22Maret2018.pdf

Efendi, A., T. Logawali, dan Musdalifah., (2016), Pengaruh Branda Image dan Inovasi Layanan terhadap Keputusan Konsumen Menggunakan Gojek di Kota Makassar. Jurnal Manajemen Ide dan Inspirasi. Vol 3(2): 1-15.

Go-jek.com., (2019), tentang go-jek. https://www.go-jek.com/about.08 Mei 2019 (23.00)

Hardian., (2018), April 23. 3 Aplikasi Ojek Online Pesaing Gojek dan Grab. Retrieved from https:/ / www.moneysmart.id/3-aplikasi-ojek-online-lokal-pesaing-go-jek-grab/

Hayati, N., (2016), Analisa Strategi Marketing Public Relations PT. Gojek dalam Memasarkan Gojek sebagai Sarana Transportasi Berbasis Teknologi. The Marketing Century. Universitas Indonesia. https:/ / doi.org/10.1002/9781119208501.ch9

Karunanithy, M., dan S, Sivesan., (2013), An empirical study on the promotional mix and brand equity: Mobile service providers. Industrial Engineering Letters, 3(3), 1-9. https:// doi.org/2225-0581

Kominfo, K., (2018), Jumlah Pengguna Internet. Retrieved from https:// kominfo.go.id/index.php/content/detail/12640/siaran-pers-no-

53hmkominfo022018-tentang-jumlah-pengguna-internet-2017-meningkat-kominfoterus-lakukan-percepatan-pembangunan-broadband/0/siaran_pers

Kotler, P., dan, K. L. Keller., (2000), Manajemen Pemasaran 301.

Lavenia, B. C., Iqbal, M., dan A., Irawan. (2018), Pengaruh Technology Acceptance Model (TAM) dan Electronic Word Of Mouth (EWOM) Terhadap Kepuasan Pelanggan. Jurnal Administrasi Bisnis (JAB), 60(3), 52-61. Retrieved from administrasibisnis.studentjournal.ub.ac.id

Maryam, dan W., Wirman., (2017), Strategi Marketing Public Relations dalam Meningkatkan Jumlah Tamu Hotel Pantai Marina Bengkalis. Jom FISIP, 4(2), 1-19.

Nur'amna, A., (2018), Analisis Efektivitas Sales Promotion pada Gojek dan Grab serta Pengaruhnya terhadap Keputusan Pengguna Transportasi Online di Kota Makassar. Skripsi. Jurusan Manajemen Fakultas Ekonomi dan Bisnis Islam Universitas Islam Negeri Alauddin Makassar.

Pratiwi, W. A., dan G. B. Rahanatha, (2016), Peran Brand Awareness Memediasi Daya Tarik Iklan terhadap Brand Attitude Indomie di Kota Denpasar. E-Jurnal Manajemen Unud, 5(12), 7899-7928.

Ridho, M., Suharyono., (2017), Pengaruh Kualitas Produk terhadap Brand Image dan Dampaknya pada Kepuasan Pelanggan (Survei pada Pelanggan Kartu Prabayar Simpati Kota Malang). Jurnal Administrasi bisnis Vol 52 (1): 124-131.

Romadhon, M.N., Zainuddin., (2018), Dampak Ojek Online terhadap Kesejahteraan Sosial (Studi Kasus pada Komunitas Independent Gojek di Yogyakarta). Skripsi. Program Studi Ilmu Kesejahteraan Sosial Fakultas Dakwah dan Komunikasi Universitas Islam Negeri Sunan Kalijaga.

Safrizal., (2015), Pengaruh Harga dan Kualitas Pelayanan terhadap Kepusan Konsumen pada Restoran Ayam Penyet Pak Ulis di Kota Langsa. Jurnal Manajemen Keuangan Vol 4 (1): 214-224.

Situmeang, L.S., (2017), Pengaruh Kualitas Pelayanan, Harga, dan Lokasi terhadap Kepuasan Konsumen pada Rumah Makan Istana Hot Plate Medan. Skripsi. Program Studi Ekonomi Islam Fakultas Ekonomi dan Bisnis Islam Universitas Islam Negeri Sumatera Utara.

Soemirat, dan Elvinaro. (2008), Marketing Public Relations. In Strategic Brand Management 24, pp. 155-172.

Syahputra, A. R., (2016), Penggunaan Technology Acceptance Model terhadap Intensi Pebisnis

jmm.unram.ac.id 
dalam Menggunakan E-Commerce. Universitas Lampung.

Tulasi, D., (2012), Marketing Communication dan Brand Awareness. Humaniora, 3(45), 215222.

Wahid, U., dan A. E. Puspita., (2017), Upaya Peningkatkan Brand Awareness PT . Go-Jek Indonesia Melalui Aktivitas Marketing Public Relations. Jurnal Komunikasi, 9(1), 31-43.

Wardani, T.U., (2017), Pengaruh Kualitas Pelayanan terhadap Kepuasan Konsumen pada Bisni Jasa Transportasi Gojek (Studi Kasus Mahasiswa FEBI UNI Sumatera Utara. Skripsi. Program Studi Ekonomi Islam Fakultas Ekonomi dan Bisnis Islam Universitas Islam Negeri Sumatera Utara..

Zahra, A., (2017), Pengaruh Kualitas Pelayanan, Persepsi Harga, dan Citra Merek terhadap Kepuasan Pelanggan Pengguna Jasa Trasnportai Ojek Online (Studi pada Pelanggana Gojek di Kota Yogyakarta). Skripsi. Program Studi Manajemen Fakultas Ekonomi Universitas Negeri Yogyarkat. 